Berger, S., Rechcigl, M. Jr., Loosli, J. K. \& Williams, H. H. (1962). F. Nutr. 77, I74.

Booth, M. A. \& Spray, G. H. (1962). Brit. F. Haemat. 8, I ro.

Bro-Rasmussen, F. (1958). Nutr. Abstr. Rev. 28, 369.

Challener, W. A. \& Korst, D. R. (1960). Amer. F. med. Sci. 240, 226.

Czaczkes, J. W. \& Guggenheim, K. (1946). F. biol. Chem. 162, 267.

Diplock, A. T., Edwin, E. E., Bunyan, J. \& Green, J. (196I). Brit. F. Nutr. 15, 425.

Esh, G. C., Bhattacharya, S. \& Som, J. M. (1960). Ann. Biochem. 20, 15.

Friend, C. J., Heard, C. R. C., Platt, B. S., Stewart, R. J. C. \& Turner, M. R. (196r). Brit. J. Nutr. I5, 231.

Gershoff, S. N. \& Andrus, S. B. (1961). F. Nutr. 73, 308.

Gershoff, S. N. \& Faragalla, F. F. (1959). F. biol. Chem. 234, 239 I.

Gopalan, C. \& Srikantia, S. G. (I960). Lancet, i, 954.

Hegsted, D. M. (1 96 r). Amer. F. clin. Nutr. 9, 548.

Horwitt, M. K., Century, B. \& Zeman, A. A. (1963). Amer. F. clin. Nutr. r2, 99

Horwitt, M. K., Harvey, C. C., Century, B. \& Witting, L. A. (1961). F. Amer. diet. Ass. 38, 231.

Hsu, J. M. (1963). Amer. F. clin. Nutr. 12, г70.

Mathews, J. \& Beaton, G. H. (1963). Canad. F. Biochem. 4I, 543 .

Morgan, T. B. \& Yudkin, J. (1957). Nature, Lond., 180, 543.

Morgan, T. B. \& Yudkin, J. (1962). Vitam. \& Horm. 20, 39.

Morrison, A. B. \& Sarett, H. P. (I959a). F. Nutr, 68, 473.

Morrison, A. B. \& Sarett, H. P. (1959b). F. Nutr. 69, I I I.

Murray, T. K. (I96r). Canad. F. Biochem. 39, ro99.

Okuda, K., Hsu, J. M. \& Chow, B. F. (1960). F. Nutr. 72, 99.

Peppler, E., Müller, B. \& Cremer, H. D. (1960). F. Nutr. 71, 9 I.

Ranke, B., Ranke, E. \& Chow, B. F. (1960). F. Nutr. 7I, 4 II.

Rechcigl, M. Jr., Berger, S., Loosli, J. K. \& Williams, H. H. (I962). F. Nutr. 76, 435.

\title{
Metabolic interrelationships in the utilization of trace elements
}

\section{By C. F. Mills, Rowett Research Institute, Bucksburn, Aberdeen}

The behaviour of the trace elements in biological systems is mostly a reflection of the strong affinity of cellular components for these elements. This behaviour can be modified by changes in the environment of the cell which influence the supply of a particular element available to participate in cellular reactions, by changes which modify cellular components in such a manner that their affinity for the element is increased or decreased, or by changes in the intra- or extra-cellular concentration of elements which compete for a specific binding site. Although in this review we are concerned with nutritional changes that may modify trace-element metabolism in the intact animal we are, in effect, dealing with these reactions. With this in mind I have selected examples of recent advances in knowledge of the influence of the nature of the diet on processes such as the liberation of trace elements from food material, the storage of these elements in the tissues, their incorporation into their functional units in the cell and finally their excretion.

\section{The influence of the type of dietary protein source on trace-element metabolism}

The nature and quantity of the protein source in a diet can have a significant effect upon the utilization of trace elements from that diet. For example, Morrison \& Sarett (1958) found that the zinc requirement of the chick is apparently increased when isolated soya-bean protein is used instead of casein or gelatin as a protein source in synthetic diets. This observation was fully confirmed by other workers, and later 
it was found by Kratzer, Allred, Davis, Marshall \& Vohra (1959) that autoclaving the soya-bean protein improved $\mathrm{Zn}$ utilization. The rates of growth of poults obtained when autoclaved soya was used were similar to those obtained by the addition of 50 p.p.m. of $\mathrm{Zn}$ to rations containing the untreated protein, and the incidence of perosis was similarly reduced by these two treatments. Speculating that the adverse effects of untreated soya protein might be due to the presence or formation of an unavailable zinc-protein complex, Kratzer et al. (1959) examined the effect of adding the chelating agent, ethylenediamine tetraacetic acid (EDTA) to the diet in an attempt to liberate bound $\mathrm{Zn}$. Additions of 227 p.p.m. EDTA markedly improved the rate of growth and reduced the incidence of perosis in poults. The efficiency with which EDTA liberates bound $\mathrm{Zn}$ from isolated soya-bean protein was later demonstrated by Davis, Norris \& Kratzer ( $1962 a$ ) - washing with a solution of it a protein sample containing $5^{\circ}$ p.p.m. Zn reduced the $\mathrm{Zn}$ content to I p.p.m. or less. In experiments with chicks the same workers (Davis et al. 1962b) demonstrated that the addition of $0.07 \%$ EDTA to diets containing isolated soya-bean protein reduced the requirements for $\mathrm{Zn}$ from 43 to $\mathrm{I} 8$ p.p.m. The influence of EDTA treatment of these diets on the availability of copper, manganese and iron was also examined. The results indicated that isolated soya-bean protein adversely affected the utilization of $\mathrm{Cu}$ and $\mathrm{Mn}$ even though it contained relatively large amounts of these elements (49 and 12 p.p.m. respectively). Utilization of both $\mathrm{Cu}$ and $\mathrm{Mn}$ was improved by EDTA supplements. There was evidence that the Fe of soya-bean protein is fully available to the chick.

Extending studies to pigs fed on practical types of diet containing soya-bean meal, Smith, Plumlee \& Beeson (1962) obtained similar results. Adverse effects were overcome by adding $5^{\circ}$ p.p.m. $\mathrm{Zn}$, by autoclaving the soya-bean meal or by the addition of $45^{\circ}$ p.p.m. EDTA to the diet. Further demonstration of the strong avidity of soya-bean protein for $\mathrm{Zn}$ is provided by work indicating that this protein affords a greater protection than casein against the toxic effects of $2500-5000$ p.p.m. $\mathrm{Zn}$ in the diet of rats (McCall, Mason \& Davis, 1961). The rate of development of anaemia was reduced, better weight gains were recorded and there was less interference with melanin-pigment formation in hair and less accumulation of $\mathrm{Zn}$ in the liver when soya-bean protein was given.

For several years it has been tacitly assumed that these effects of soya-bean protein are related to the formation of strong metal-protein complexes that do not decompose during digestion to yield the trace metal in a readily available form. This may well be so-it has yet to be proved or disproved-but recent evidence pointing to the fact that the so-called pure isolated soya-bean proteins contain non-protein fractions that have a strong affinity for several trace elements has stimulated a re-examination of these opinions, as will be shown.

Apart from the examples described above, the nature of the protein source does not dramatically influence the availability of trace elements as judged from studies in which $\mathrm{Cu}$ and $\mathrm{Zn}$ were readily utilized when given to rats or chicks as a range of metal 'proteinates' (Schultze, Elvehjem \& Hart, 1934; Pensack, Henson \& Bogdonoff, 
I958), and from the work of Forbes \& Yohe (1960) who found that the $\mathrm{Zn}$ requirement of the rat was approximately the same when either casein or dried egg-white was used as the protein source. However, it has been noted in one series of experiments that the increase in rate of weight gain and food conversion efficiency of pigs after the addition of 250 p.p.m. Cu to the diet are smaller when the diet contains vegetable rather than animal protein (Barber, Braude \& Mitchell, 1962). It is also apparent that high levels of dietary protein afford greater protection against excessive tissue accumulation and the toxic effects of $\mathrm{Cu}$ (McCall \& Davis, I96r; Lucas, Livingstone \& Boyne, I962; Wallace, McCall, Bass \& Combs, I960), Zn (McCall et al. 1961), molybdenum (Leach, Turk, Zeigler \& Norris, 1962) and selenium (Smith, 1939).

\section{Other organic components of the diet influencing trace-element utilization}

O'Dell \& Savage (1960), noting that soya-bean meal is rich in phytate and that this phytate is co-precipitated with protein during the commercial preparation of 'isolated soya-bean protein' (Smith \& Rackis, 1957), re-examined previous work on the low availability of $\mathrm{Zn}$ in diets containing soya-bean preparations in the light of the possibility that this effect might be due to formation of a complex between $\mathrm{Zn}$ and phytate or phytic acid. Using basal diets with 9 p.p.m. zinc they compared the rates of growth of chicks fed on diets containing a casein-phytic acid preparation or isolated soya-bean protein at levels providing approximately the same amount of phytic acid. Compared with diets containing untreated casein, poor growth was obtained on both diets unless supplements of $\mathrm{Zn}$ were added. Growth suppression on the casein-phytic acid preparation was less marked than with soya-bean protein. The addition of the calcium salt of phytic acid to the casein diet apparently had no effect in reducing $\mathrm{Zn}$ availability, from which the authors concluded that either it was necessary for the phytic acid to be associated with protein to have a $Z n$-binding effect, or that the low solubility of calcium phytate prevents its reaction with $\mathrm{Zn}$.

The $\mathrm{Zn}$-binding effect of phytic acid or its protein complexes has also been noted in experiments with pigs. Green, Plumlee, Smith, Parker \& Beeson (196I) found that supplements of phytic acid $(0.6 \%)$ added to basal rations containing soya-bean meal increased the number of cases of parakeratosis and decreased the rate of growth. Phytic acid increased faecal $\mathrm{Zn}$ excretion and decreased tissue storage; these effects disappeared when $45^{\circ}$ p.p.m. EDTA were included in the diet. Someimprovement in growth rate was obtained by reducing the $\mathrm{Ca}$ content of the diet from 0.78 to $0.4 \mathrm{I} \%$. Oberleas, Muhrer \& O'Dell ( 1962 ) carried out a study with pigs fed on diets containing soya-bean meal or the casein-phytic acid complex which confirmed in outline their earlier work with chicks. They also found that reducing the Ca content of the diet improved $\mathrm{Zn}$ utilization when phytic acid was present but not when it was absent.

These studies of relationships between $\mathrm{Zn}$, soya-bean protein and phytic acid have been dealt with in detail because they pose a number of questions which merit consideration. Thus in none of the trials reported above has the addition of phytic 
acid to a casein diet produced the same depression of physiological performance as the same quantity of phytic acid present in soya-bean meal or soya-bean protein. Judged by the responses obtained by adding $Z_{n}$ supplements, lack of available $Z_{n}$ was the only limiting factor. Interference caused by the formation of a $\mathrm{Zn}$ complex with phytic acid may account for most of these effects but there is also a residual effect of the protein source reducing $\mathrm{Zn}$ availability. Interaction with phytic acid may underlie at least part of the observed effects of sesame meal (Turk, Lease \& Clemson, 1962) and pea meal (Kienholz, Jensen \& McGinnis, 1959) in reducing the availability of $\mathrm{Zn}$. Both these products have a high content of phytate.

Phytic acid and its salts may also influence the availability of other trace elements. $\mathrm{Zn}$ is by no means unique in forming compounds of low solubility with phytic acid. We have already discussed experiments in which protein sources also containing phytic acid have been shown to restrict the utilization of dietary $\mathrm{Cu}$ and Mn (Davis et al. $1962 b$ ) and it is possible that the availability of molybdenum may be adversely affected in the same way (Leach et al. 1962). Furthermore, it has long been known that soluble phytates can reduce the availability of dietary Fe (Sharpe, Peacock, Cook \& Harris, 1950). Much more must be known about the stability and solubility of trace-metal phytates before their importance in limiting trace-element uptake can be assessed. Many contradictory reports have appeared concerning the influence of dietary calcium and phosphorus levels on trace-element availability, as has, for example, been pointed out by Forbes (1960). It is perhaps not merely coincidence that studies of the influence of phytic acid and phytase on $\mathrm{Cu}$ and $\mathrm{P}$ utilization have revealed an equally complex situation which is being gradually resolved (Roberts \& Yudkin, $19^{6} \mathrm{r}$ ).

Relatively little is known about the influence of other organic components of the diet on the utilization of trace elements. Many food materials contain components which readily combine with such elements to form stable complexes, and it might be inferred from their structure and solubility that many of these complexes are poor sources of trace elements for the animal. Thus Deijs \& Bosman (1961), investigating earlier observations that the $\mathrm{Cu}$ status of cattle often falls during the summer grazing period and improves during winter even on diets containing less $\mathrm{Cu}$, investigated the stability of $\mathrm{Cu}$ complexes of phaeophytin, the degradation product of chlorophyll. Copper phaeophytin was readily formed on treating aqueous suspensions of dried grass with ionic $\mathrm{Cu}$; the isolated product was stable in the presence of sulphide or chelating agents. $\mathrm{Cu}$ in the structurally related compound, copper haematoporphyrin, has been shown to be unavailable to the rat (Schultze et al. 1934). The study of the stability of copper phaeophytin in acid solution by Deijs \& Bosman (1961) indicates that only below $\mathrm{pH}_{3 \cdot 2}$ is decomposition to yield ionic $\mathrm{Cu}$ appreciable; the $\mathrm{pH}-$ stability relationship obtained was almost identical to that found by Mills (1956) for $\mathrm{Cu}$ in grass extracts after peptic digestion in vitro. Further studies on the availability to the animal of $\mathrm{Cu}$ as its phaeophytin complex are awaited with interest.

The nature of the Se compounds in a diet markedly influences the potency of this element both in protecting against deficiency and in causing toxin effects. Schwarz (1961) has demonstrated that Factor 3, an as yet unidentified organo-Se compound, 
is at least three times as effective in protecting rats against dietary necrotic liver degeneration as inorganic Se compounds. In studies on Se poisoning in the rat it has been shown that there is a greater accumulation of Se in the liver when it is given as seleniferous wheat than when it is given in inorganic form (Halverson, Guss \& Olson, 1962). The organic Se compounds responsible for this effect have not yet been identified.

\section{The influence of inorganic ions in modifying trace-element metabolism}

Examination of recent work on the metabolism of trace elements indicates that utilization may be influenced by the presence of abnormal quantities of certain ions which may either (r) modify normal transport of trace elements through cell membranes, (2) compete with these elements for their active functional sites within the cell or (3) affect the normal distribution of trace elements between cell components. In the animal, these effects often result in an increased dietary requirement for a specific trace element and the processes involved are thus regarded as antagonistic or 'conditioning' effects of the added ion. For clarity the subsequent discussion of selected examples of these processes is grouped according to the trace elements involved.

Copper-molybdenum relationships. The metabolism of $\mathrm{Cu}$ is markedly affected by the dietary content of Mo (Arthur, Motzok \& Branion, r958; Dick, I956; Mills \& Fell, I 960). The magnitude of this effect of Mo is in turn influenced by the level of sulphur-containing compounds in the diet, and the nature of this interaction differs in different species. In the non-ruminant animal supplements of molybdate salts depress growth and may restrict haemoglobin production. This situation is largely prevented if the $\mathrm{Cu}$ intake is increased; it is also prevented by increasing either the sulphate content of the diet or the content of organic S compounds that are subsequently metabolized to sulphate. In essence the antagonistic effects of Mo on $\mathrm{Cu}$ utilization are therefore overcome by increasing the circulating level of sulphate. In contrast, the sulphate ion, and probably $\mathrm{S}$ in amino acids, acts as a synergist to the effects of Mo in causing Cu depletion in the ruminant (Dick, 1956). It is becoming apparent that these effects are probably related to differences in the pathways of S metabolism in ruminant and non-ruminant animals and the relationship of these differences to Mo storage and excretion will be considered later. However, it is important to note at this stage that several workers have observed that Mo exerts its adverse effect on $\mathrm{Cu}$ utilization in the rat not by preventing $\mathrm{Cu}$ absorption but by apparently restricting its mobilization from tissue stores. It has been shown, for example, that in rats receiving Mo supplements liver $\mathrm{Cu}$ stores may be abnormally high and yet supplementary $\mathrm{Cu}$ improves growth (Comar, Singer \& Davis, I949; Miller, Price \& Engel, 1956). Liver-fractionation experiments indicate a direct relationship between the $\mathrm{Cu}$ and Mo contents of all particulate fractions of the liver cell in animals given Mo, suggesting that this $\mathrm{Cu}$-binding effect is a generalized phenomenon not associated with any individual structure of the cell (C. F. Mills \& R. L. Mitchell, to be published). It has been suggested that depletion of Cu reserves in the ruminant given Mo and sulphate results from an increase in Cu excretion. On 
the other hand, it has been shown that such diets depress the content of soluble $\mathrm{Cu}$ in rumen and abomasum liquors, suggesting that $\mathrm{Cu}$ absorption may be impaired (Mills, I960).

Molybdenum-sulphur relationships. Dietary supplements containing inorganic sulphate promote the urinary excretion of Mo in the rat and the sheep and restrict or completely prevent its accumulation in the liver (Miller et al. 1956). The effect of sulphate in preventing Mo intoxication is shared by many organic $\mathrm{S}$ compounds that are oxidized to sulphate during metabolism, as has been shown by Van Reen \& Williams (1956), Dick (1956) and Miller \& Denton (1959). In contrast the presence of sulphides in the diet has been found to aggravate Mo toxicity in the rat (Mills, I960). Further studies of this point have led to the finding that Mo intoxication restricts the oxidation of sulphide in liver tissue (Mills, Monty, Ichihara \& Pearson, 1958). This result explains why organic $\mathrm{S}$ compounds, e.g. methionine, that are normally degraded by a pathway involving endogenous release of sulphide and its subsequent oxidation to sulphate, fail to protect against Mo intoxication if Mo has already accumulated in the tissues (Halverson, Phifer \& Monty, I960). It has been further suggested that the accumulation of endogenous sulphide in such animals and the reaction of sulphide with tissue $\mathrm{Cu}$ to form insoluble cupric sulphide is the reason for the accumulation of physiologically unavailable $\mathrm{Cu}$.

Molybdenum-tungsten relationships. Adverse effects upon growth and upon the activity of the molybdoflavo-protein enzyme, xanthine dehydrogenase, have been noted in rats (Higgins, Richert \& Westerfeld, r956) and chicks (Teekell \& Watts, I $959 a, b)$ given dietary supplements containing tungstates. These effects are reversed by increasing the content of molybdates in the diet, which suggests a direct antagonism between these two ions either in promoting Mo excretion or by reducing the activity of enzymes containing Mo (Westerfeld, Richert \& Higgins, I957).

Interactions between $\mathrm{Fe}, \mathrm{Cu}$ and $\mathrm{Zn}$. Matrone (1960) has critically reviewed recent work on $\mathrm{Cu}-\mathrm{Fe}$ relationships and has concluded, contrary to earlier opinions, that there is little evidence to suggest that $\mathrm{Cu}$ influences $\mathrm{Fe}$ absorption other than by diminishing the need for $\mathrm{Fe}$ during $\mathrm{Cu}$-deficiency anaemia. There is, however, an interaction between $\mathrm{Cu}$ and $\mathrm{Fe}$ for haemoglobin synthesis in the rat (Matrone, I960; R. B. Williams \& C. F. Mills, unpublished results) and the chick (Hill \& Matrone, I96I). At suboptimal levels of $\mathrm{Fe}$ intake, increased supplementation with $\mathrm{Cu}$ produces a small increase in haemoglobin level; the same is true of increases in Fe level when $\mathrm{Cu}$ intake is suboptimal. The mechanism of this interaction is obscure, but it may also apply in the synthesis of the Fe-containing enzyme, catalase, and, if so, would explain earlier controversy about whether $\mathrm{Cu}$ deficiency reduces catalase activity (Adams, I953; Gubler, Cartwright \& Wintrobe, I957).

\section{Interactions between trace metals during trace-metal intoxication}

Experiments with metal-containing enzymes and other metallo-proteins have clearly shown that, when their environment contains abnormally high concentrations of some elements, reactions can occur which result in displacement of the native metal and its replacement by another (cf. Plocke \& Vallee, I962; Breslow \& Gurd, 1963). 
Such changes often profoundly influence the biological reactivity of the metalloprotein. These reactions probably account for the complex nature of responses to trace-element intoxication in animals.

Thus $\mathrm{Zn}$ intoxication results in depression of the activity of the Fe enzyme, catalase, and the $\mathrm{Cu}$ enzyme, cytochrome oxidase (Van Reen, I953; Cox \& Harris, 1960). Growth inhibition, anaemia and reduced liver concentrations of $\mathrm{Fe}$ and $\mathrm{Cu}$ accompany this situation. Cox \& Harris (1960) are of the opinion that the primary metabolic defect in $\mathrm{Zn}$ intoxication is an induced $\mathrm{Cu}$ deficiency which, in turn, results in poor utilization of $\mathrm{Fe}$. Cox \& Harris ( 1962 ) later showed that high levels of $\mathrm{Zn}$ in the diet of rats also cause extensive depletion of tissue stores of ferritin and haemosiderin and depress the activity of the Mo- and Fe-containing enzyme, xanthine oxidase, in the liver.

Similarities in the chemical properties of cadmium and $\mathrm{Zn}$ have led to suggestions that $\mathrm{Cd}$ might also interfere with $\mathrm{Cu}$ and $\mathrm{Fe}$ metabolism. This antagonism has recently been demonstrated by Hill, Matrone \& Payne (1963) in work with rats. High intakes of manganese have similarly been shown to interfere with $\mathrm{Fe}$ metabolism (Matrone, Hartman \& Clawson, 1959).

A recent study of $\mathrm{Cu}$ intoxication in the pig again suggests that $\mathrm{Cu}$, in excess, interferes with $\mathrm{Fe}$ and $\mathrm{Zn}$ metabolism (N. F. Suttle, to be published). Intoxication with $\mathrm{Cu}$ caused anaemia, growth restriction and a rise in serum aspartate aminotransferase (SAAT) and ornithine carbamoyltransferase (OCT) levels, indicating liver damage. Increasing the $\mathrm{Zn}$ level of the diet prevented the rise in SAAT level but had no effect on the development of anaemia. Fe supplementation prevented both the appearance of anaemia and the rise in SAAT and OCT levels.

\section{Conclusion}

From the examples quoted above of the influence of dietary components on traceelement metabolism it is hardly surprising that our knowledge of the trace-element requirements of many animals is imprecise. Trace-element deficiency disorders are rare in man, presumably because of varied diet. With other animals it is not so. Recent trends towards the simplification of diets, often with the inclusion of components which may adversely influence availability, appear to be accentuating these problems. This is particularly so when diets are formulated on the basis of known energy and protein requirements to provide for the maximum exploitation of productive potential. Under these circumstances inadequacies in trace-element supply are revealed that are not apparent in animals maintained at lower levels of production. The sudden appreciation of the existence of this problem and of our present inadequate knowledge of the influence of diet on trace-element metabolism is reflected by a great increase of interest in this field of nutritional research.

\section{REFERENCES}

Adams, D. H. (1953). Biochem. Y. 54, 328.

Arthur, D., Motzok, I. \& Branion, H. D. (1958). Poult. Sci. 37, г г8 I.

Barber, R. S., Braude, R. \& Mitchell, K. G. (I962). Anim. Prod. 4, 233.

Breslow, E. \& Gurd, F. R. N. (r963). F. biol. Chem. 238, I332. 
Comar, C. L., Singer, L. \& Davis, G. K. (1949). F. biol. Chem. r8o, 913.

Cox, D. H. \& Harris, D. L. (1960). F. Nutr. 7o, 5 I4.

Cox, D. H. \& Harris, D. L. (1962). F. Nutr. 78, 415.

Davis, P. N., Norris, L. C. \& Kratzer, F. H. (1962a). F. Nutr. 78, 445.

Davis, P. N., Norris, L. C. \& Kratzer, F. H. (1962b). F. Nutr. 77, 217.

Deijs, W. B. \& Bosman, M. S. M. (rg6r). faarb. Inst. Biol. Scheik. Ond. Landbouzog. no. 1 59, p. 93.

Dick, A. T. (1956). In Inorganic Nitrogen Metabolism, p. 445. [W. D. McElroy \& B. Glass, editors.] Baltimore: Johns Hopkins Press.

Forbes, R. M. (1960). Fed. Proc. 19, no. 2, p. 643.

Forbes, R. M. \& Yohe, M. (1960). I. Nutr. 70, 53 .

Green, J. D., Plumlee, M. P., Smith, W. H., Parker, H. E. \& Beeson, W. M. (1961). J. Anim. Sci. 20, 933 .

Gubler, C. J., Cartwright, G. E. \& Wintrobe, M. M. (1957). F. biol. Chem. 224, 533.

Halverson, A. W., Guss, P. L. \& Olson, O. E. (1962). F. Nutr. 77, 459.

Halverson, A. W., Phifer, J. H. \& Monty, K. J. (1960). F. Nutr. 71, 95.

Higgins, E. S., Richert, D. A. \& Westerfeld, W. W. (1956). F. Nutr. 59, 539.

Hill, C. H. \& Matrone, G. (rg6i). F. Nutr. 73, 425 .

Hill, C. H., Matrone, G. \& Payne, W. L. (1963). Fed. Proc. 22, no. 3, p. 378.

Kienholz, E. W., Jensen, L. S. \& McGinnis, J. (1959). Poult. Sci. 41, 367.

Kratzer, F. H., Allred, J. B., Davis, P. N., Marshall, B. J. \& Vohra, P. (x959). F. Nutr. 68, 313.

Leach, R. M. Jr., Turk, D. E., Zeigler, T. R. \& Norris, L. C. (1962). Poult. Sci. 4r, 300.

Lucas, 1. A. M., Livingstone, R. M. \& Boyne, A. W. (1962). Anim. Prod. 4, 177.

MeCall, J. T. \& Davis, G. K. (1961). F. Nutr. 74, 45.

McCall, J. T., Mason, J. V. \& Davis, G. K. (1961). F. Nutr. 74, 5 I.

Matrone, G. (1960). Fed. Proc. 19, 659.

Matrone, G., Hartman, R. H. \& Clawson, A. J. (1959). F. Nutr. 67, 309.

Miller, E. C. \& Denton, C. A. (1959). Poult. Sci. 38, 9 10.

Miller, R. F., Price, N. O. \& Engel, R. W. (I956). F. Nutr. 60, 539.

Mills, C. F. (1956). Biochem. F. 63, 187.

Mills, C. F. (1960). Proc. Nutr. Soc. 19, 162.

Mills, C. F. \& Fell, B. F. (1960). Nature, Lond., 185, 20.

Mills, C. F., Monty, K. J., Ichihara, A. \& Pearson, P. B. (1958). F. Nutr. 65, I29.

Morrison, A. B. \& Sarett, H. P. (1958). F. Nutr. 65, 267.

Oberleas, D., Muhrer, M. E. \& O'Dell, B. L. (1962). F. Anim. Sci. 21, 57.

O'Dell, B. L. \& Savage, J. E. (I 960). Proc. Soc. exp. Biol., N.Y., ro3, 304.

Pensack, J. M., Henson, J. N. \& Bogdonoff, P. D. (1958). Poult. Sci. 37, 232.

Plocke, D. J. \& Vallee, B. L. (1962). Biochemistry, 1, 1039.

Roberts, A. H. \& Yudkin, J. (1961). Brit. F. Nutr. 15, 457.

Schultze, M. O., Elvehjem, C. A. \& Hart, E. B. (1934). Y. biol. Chem. ro6, 735.

Schwarz, K. (r961). Fed. Proc. 20, no. 2, p. 666.

Sharpe, L. M., Peacock, W. C., Cook, R. \& Harris, R. S. (1950). F. Nutr. 41, 433.

Smith, A. K. \& Rackis, J. J. (1957). F. Amer. chem. Soc. 79, 633.

Smith, M. I. (1939). Publ. Hlth Rep., Wash., 54, I441.

Smith, W. H., Plumlee, M. P. \& Beeson, W. M. (1962). F. Anim. Sci. 21, 399.

Teekell, R. A. \& Watts, A. B. (1959a). Poult. Sci. 38, 791.

Teekell, R. A. \& Watts, A. B. (1959b). Poult. Sci. 38, 1 127.

Turk, D. E., Lease, J. G. \& Clemson, S. C. (1962). Fed. Proc. 21, no. 2, p. 3 I I.

Van Reen, R. (1953). Arch. Biochem. Biophys. 46, 337.

Van Reen, R. \& Williams, M. A. (1956). Arch. Biochem. Biophys. 63, x.

Wallace, H. D., McCall, J. T., Bass, B. \& Combs, G. E (ig60). J. Anim. Sci. 19, II 53.

Westerfeld, W. W., Richert, D. A. \& Higgins, E. S. (1957). F. biol. Chem. 227, 379.

\title{
Nutrient interrelationships as they affect the formulation of balanced diets
}

\author{
By L. E. Lloyd, Department of Animal Science, Macdonald College (McGill \\ University), Province of Quebec, Canada
}

In 1963 , and for that matter during the years immediately ahead of us, there is not a more important topic in nutrition than the effect of nutrient interrelationships 